\title{
SMART GROWTH IN LATGALE REGION OF LATVIA: AN OVERVIEW OF MULTIPLE-HELIX ACTORS
}

\author{
Ludmila ALEKSEJEVA, Department of Economic and Sociology, Daugavpils University, Parādes str. 1-331, Daugavpils, Latvia, \\ ludmila.aleksejeva@du.lv (corresponding author) \\ Viktorija ŠIPILOVA, The Institute of Humanities and Social Sciences, Daugavpils University, Parādes str. 1-422, Daugavpils, Latvia, \\ viktorija.sipilova@du.lv \\ Elita JERMOLAJEVA, Latvia University of Agriculture, Svētes str. 18, Jelgava, Latvia, elita.jermolajeva@gmail.com \\ Inta OSTROVSKA, The Institute of Humanities and Social Sciences, Daugavpils University, Parādes street 1-331, Daugavpils, \\ Latvia, inta.ostrovska@du.lv \\ Dmitrijs OL̦EHNOVIČS, Faculty of Social Sciences, Daugavpils University, Parādes str. 1-331, Daugavpils, Latvia, \\ dmitrijs.olehnovics@du.lv
}

\begin{abstract}
Within the framework of the Latvian National Programme EKOSOC-LV this paper focuses on the smart growth as a tool for regional development. The research aim is to evaluate the factors that influence the formation of a smart territory and to estimate interconnections of quantitative indicators and expert opinions. The present study reflects the quantitative and qualitative assessment of smart growth challenges in the region of Latgale (Latvia) on the level of 19 districts. One of the most important aspects of the implementation of the concept of smart specialization is the participation of all involved actors; thus, one of the solutions of smart growth evaluation is the multiple helix approach. By analysing and summarizing the aspects affecting smart territories, based on the theoretical principles, regional stakeholder's (local governments, entrepreneurs, representatives of communities, scientists, general public) recommendations, taking into account the national strategic settings and the views of the EKOSOC-LV working group, smart growth index was developed as well as factor hierarchy of the smart territory formation and growth, on the basis of which the Analytic Hierarchy Process method was realized. Logical construction, monographic, analytic hierarchy process, statistical analysis methods are used for research. The quantitative assessment is based on integrated index (Smart Development Index) establishment and testing. The qualitative assessment is based on the regional expert opinions summarized by the Analytic Hierarchy Process methodology. Complex analysis of the obtained quantitative indicators highlights the People and Resources dimension, but qualitative assessment underlines People and Economy dimensions as the keystones of the smart specialization of the Latgale region. The integrated application of quantitative and qualitative approaches allows a comprehensive assessment of the smart growth process in the Latgale region and its districts.
\end{abstract}

Keywords: multiple-helix, Latgale region, Analytic Hierarchy Process, smart growth, smart development index

\section{THEORETICAL BACKGROUND}

Based on the experience found in the scientific literature, the authors of the study consider that the view expressed in the context of the new development paradigm regarding the use of each territory's potential (e.g., Vanthillo, Verhecel 2012) also clearly highlights the potential of small rural areas to engage in the process of smart specialization. By summing up the European and the USA experience in providing smart growth, Šipilova et al. (2017) concludes that small rural areas also have ample opportunities to develop smart specialization and that the emphasis on specific indicators can only lead to a misunderstanding of small rural areas for their potential to be involved in this process.

One of the most important aspects of implementing the concept of smart specialisation is the participation of all involved actors (Krueger 2010, Using the Quadruple Helix Approach, EU, 2016), thus one of the solutions of smart growth evaluation is the multiple helix approach. The purpose of this paper is to analyse smart growth aspects in local territories by applying a multiple helix approach, emphasizing relationships between industry, government, business, society and the natural environment. The multiple helix is a way of conceptualising the linkages between different actors and those roles, or functions, over time, and the relationships among the key operational elements in a regional development perspective (Carayannis and Campbell, 2006, 2012). Methodological challenges related to the implementation of smart specialization are topical in Latvia (Śipilova et al., 2015 ) also in Lithuania, and as concluded by Poliakaite et al. (2015), the development and implementation of the concept of smart specialization at the local level require active process of clarification and discussion involving all interested parties. Furthermore, Multiple Helix has been identified as the reference approach for the

Copyright (C) 2017 The Authors. Published by Aleksandras Stulginskis University. This is an open-access article distributed under the terms of the Creative Commons Attribution License (CC-BY 4.0), which permits unrestricted use, distribution, and reproduction in any medium, provided the original author and source are credited. 
preparation and implementation of the Research and Innovation Strategies for Smart Specialisation (RIS3) (RIS3 Guide EC, 2012).Wider engagement of stakeholders as well as combining qualitative and quantitative methods provides for a more detailed and comprehensive approach in smart growth and regional development.

\section{REGIONAL DEVELOPMENT IN LATVIA}

The territory of the Latgale region is 14.5 thousand $\mathrm{km}^{2}(22.5 \%$ of the total area of the country) and it is located in the Eastern part of Latvia and is bordered by the Republic of Lithuania (length of the borderline is $57 \mathrm{~km}$ ). It has 253.2 $\mathrm{km}$ long borderline, which is also the EU's external border, including in the East a $166.2 \mathrm{~km}$ long borderline with the Russian Federation and in the South-east a $87 \mathrm{~km}$ long borderline with Belarus. There are 21 municipalities in the Latgale region, including 2 cities of republic importance - Daugavpils and Rēzekne, as well as 19 districts.

Improvements in the welfare of the region within the framework of the new regional development paradigm should be linked to strengthening the competitiveness of the territories through its potential (e.g. ESPON, University Rovira i Virgil 2012; Šipilova et al., 2015), i.e. its resources, social capital, technology, effective governance, institutional capacity. Applying the right accent in the region's development is a great challenge for each region. The development of an integral indicator (Smart Development Index), which includes all the dimensions necessary for the development of the entire region (Resources, People, Economy and Governance), makes it possible to identify the development trends of the Latgale Region with a new breeze.

\section{RESEARCH DISCUSSION AND RESULTS IN LATGALE REGION}

There is a Smart Development Index (SDI) developed by EKOSOC-LV research team as well on the basis of the SDI the data was collected in Latgale region (see Table 1). In general, the descriptive statistical data on the values of the smart development index show that the Latgale region is still lagging behind other regions according to the level of smart development, however, smart growth is more even in the region; however, regions with higher levels of smart development develop more slowly than those with lower levels of smart growth (Šipilova et al., 2017). The Smart Development Index in Latgale districts reflects the division of districts into two similar groups, where the first group has 10 districts with positive values of the index and the second group has 9 districts with negative index values (Šipilova et al., 2017).

According to the values of the Four Dimensions of the Smart Development Index in the Latgale region districts, it is possible to determine the dominant dimension of the index structure for each district. The overall trend demonstrates a distinct dominance of the dimension Governance in both the districts with positive and negative Smart Development Index values. Thus, the Governance Indicator shows higher values in 9 districts, however, mostly (in 5 districts) in the group of districts with negative index values. However, Governance is the dominant dimension of the Smart Development Index in Ilūkste district, which holds the first rate in the Latgale region according to smart growth.

By analysing and summarizing the aspects affecting smart territories, and on the basis of theoretical viewpoints, the recommendations of stakeholders (local authorities, entrepreneurs, community's representatives), by taking into account national strategic settings and the opinions of the EKOSOC-LV working group, the hierarchy of smart territory formation and its development factors were created, and the accents by local experts in the evaluation of factors and development visions were assessed. The AHP method was used to analyse the formation of a smart territory and its development scenarios. The formation and development of a smart territory is influenced by factors of four group: impact of the people, impact of local governments, state impact and impact of the EU. 16 evaluation criteria were selected, which were grouped according to the interests of target groups (people, local governments, state and EU interest groups). 6 experts were chosen and selected in Latgale, representing the interests of the involved directions and factors: experts, who are related to the operation of the local government, or are representatives of the region in the central government; experts representing the interests of the local people; experts - highly qualified scientists in the field of regional development research; entrepreneurs and representatives of entrepreneurship environment.

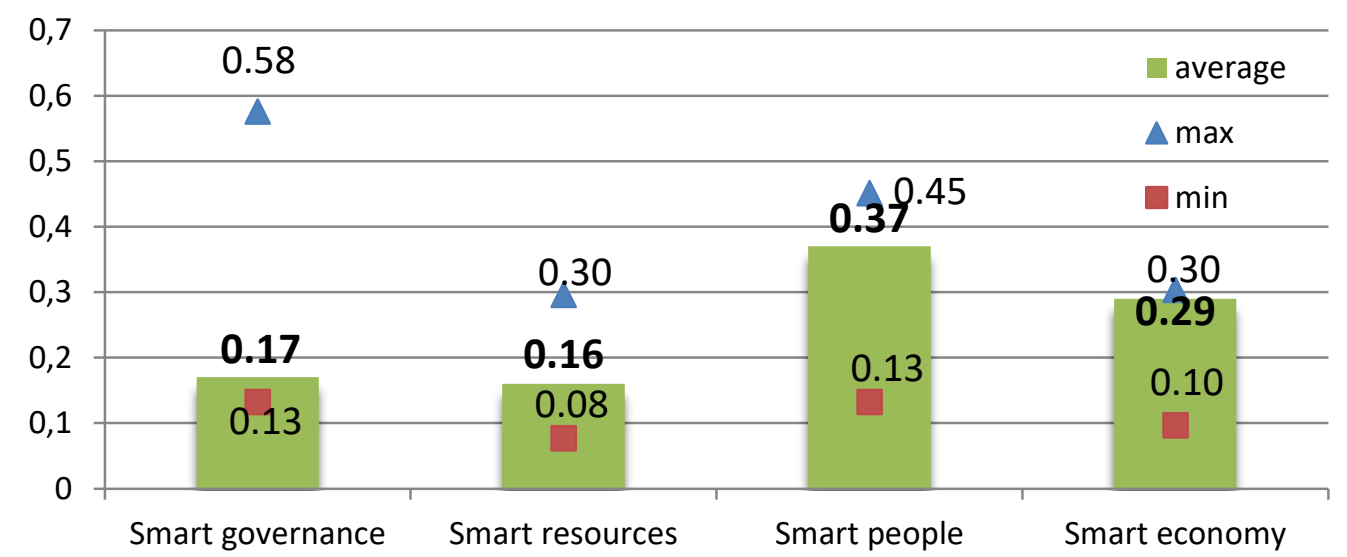

Source: EKOSOC-LV data

Figure 1. Overall, minimum and maximum ratings of Level 1 factor groups for Latgale region as viewed by the experts (n=6) 
According to the opinion of the experts surveyed, the dimensions People (0.37) and Economy (0.29) have the greatest importance for ensuring smart growth. Equally, according to the experts' point of view, the dimensions Governance (0.17) and Resources (0.16) have the less importance for the smart development process (see Figure 1). By combining the quantified trends of smart growth in the Latgale region with expert assessment (qualitative assessment) on the role of the Smart Development Index dimension in smart growth in the Latgale region, it is possible to characterize certain smart growth trends (see Table 1).

Table 1. The dominant dimensions of the Latgale region's smart growth according to the results of quantitative and qualitative assessment

\begin{tabular}{|l|l|l|}
\hline \multicolumn{1}{|c|}{ Smart Development Index } & Dimensions \\
Quantitative and qualitative & \\
characteristics & & \\
\hline The dimension has a closer relation to the Smart Development Index in the Latgale region & & \\
\hline $\begin{array}{l}\text { The dimension has a dominant position in the group of districts with positive values of the Smart } \\
\text { Development Index }\end{array}$ & & \\
\hline $\begin{array}{l}\text { The dimension has a dominant position in the group of district with negative values of the Smart } \\
\text { Development Index }\end{array}$ & & \\
\hline The dimension plays a major role according to state, business and scientific experts' point of view & & \\
\hline
\end{tabular}
Source: Šipilova et al. 2017.

The brightest trend of smart growth in the Latgale region is attributed to the fact that the dimensions Resources and Economy are not found among the dominant dimensions, neither in terms of quantitative, nor qualitative assessment. This could be explained by the well-known negative tendencies in the Latgale region regarding Resources and Economy, which are also reflected in experts' perceptions. These unfavourable trends are low business activity (attributable to the dimension Economy) and the use of natural resources to create low added value (attributable to the dimension Resources). By being aware of the regions' commitment to move towards promoting knowledge-based development, it would be worthwhile to focus on analysing the growth of business in a knowledge-based segment of economy as compared to the growth of business in the economy as a whole.

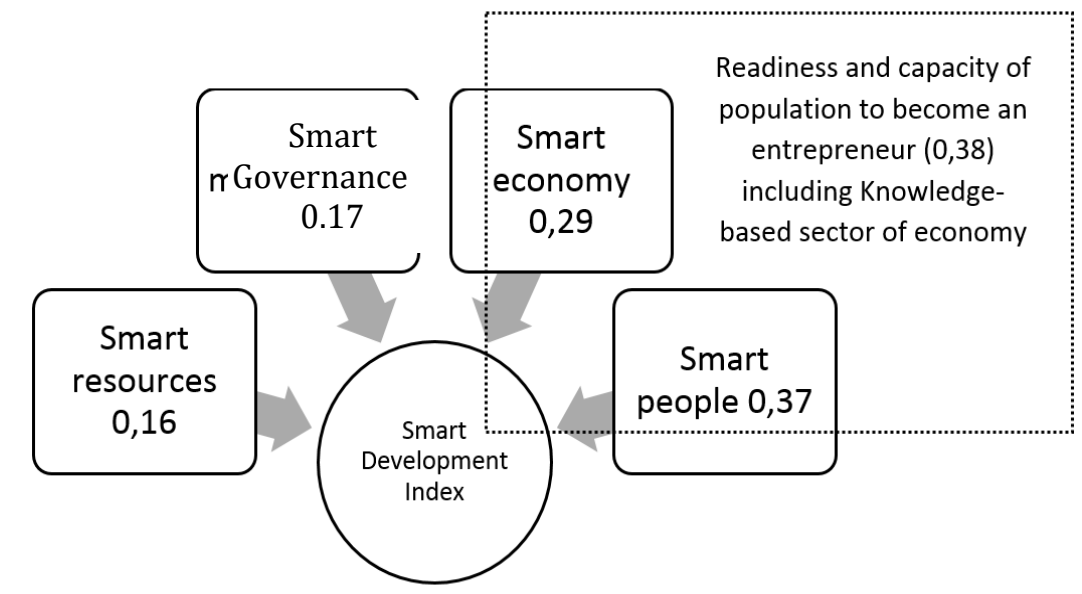

Source: EKOSOC-LV data

Figure 2. Experts' opinion on the factors influencing smart growth of the Latgale region

According to the experts' assessment, one of the most important factors for ensuring smart growth in the Latgale region is related to the dimension People. In turn, according to experts, the involvement of people in business is the most important factor as the people can influence smart growth in the region (see Figure 2).

Data analysis on business growth allows to highlight significant tendencies. When analysing the business growth, the authors take into account not only the dynamics of the number of companies, but also the characteristics of the districts of the Latgale region according to the development level and pace, as well as the population.

The average increase in the number of companies in the group of districts with a high economic development $(+107.7 \%)$ is significantly higher than in the KBE segment $(+60.50 \%)$. In comparison, in the group of districts with a low development level the increase in the number of companies in the KBE segment $(+137.81 \%)$ is greater than in the economy as a whole $(+80.43 \%$ ) (see Table 2$)$. The analysed data allows us to highlight the existence of both positive and negative trends. For example, it is positive that in the lower-developed districts the KBE segment shows a faster growth, however, at the moment, this trend has not yet been reflected in improving the development level of the districts. As a negative trend, the modest growth of the KBE segment in the districts with a higher development level should be noted, which indicates the shift of emphasis in economic activity away from the KBE segment. 
Table 2. The increase in the number of companies in the districts of the Latgale region according to the development level and rate

\begin{tabular}{|c|c|c|c|}
\hline \multirow{2}{*}{\multicolumn{4}{|c|}{ 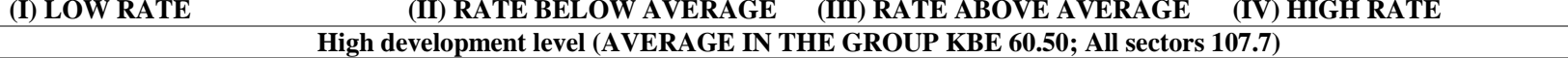 }} \\
\hline & & & \\
\hline DISTRICTS: & DISTRICTS: & DISTRICTS: & DISTRICTS: \\
\hline AVERAGE IN THE GROUP & AVERAGE IN THE GROUP & AVERAGE IN THE GROUP & AVERAGE IN THE GROUP \\
\hline KBE 68.78 & KBE 25.00 & KBE 94.44 & KBE 100.00 \\
\hline All sectors 53.4 & All sectors 70.75 & All sectors 43.46 & All sectors 500.00 \\
\hline Krāslavas & Balvu & Daugavpils & Vārkavas \\
\hline $\mathrm{KBE}+50.00$ & $\mathrm{KBE}+50.00$ & $\mathrm{KBE}+94.44$ & $\mathrm{KBE}+100.00$ \\
\hline All sectors 57.03 & All sectors 50.96 & All sectors 43.46 & All sectors 500.00 \\
\hline Līvānu & Rugāju & & \\
\hline $\mathrm{KBE}+69.57$ & $\mathrm{KBE}-50.00$ & & \\
\hline All sectors 49.69 & All sectors 83.33 & & \\
\hline Preil̨u & Ilūkstes & & \\
\hline $\mathrm{KBE}+100.00$ & $\mathrm{KBE}+75.00$ & & \\
\hline All sectors 58.91 & All sectors 77.97 & & \\
\hline \multicolumn{4}{|l|}{ Ludzas } \\
\hline \multirow{2}{*}{\multicolumn{4}{|c|}{$\begin{array}{l}\text { KBE }+55.56 \\
\text { All sectors } 47.97\end{array}$}} \\
\hline & & & \\
\hline \multicolumn{4}{|c|}{ Low development level (AVERAGE IN THE GROUP KBE 137.81; all sectors 80.43) } \\
\hline DISTRICTS: & DISTRICTS: & DISTRICTS: & DISTRICTS: \\
\hline AVERAGE IN THE GROUP & AVERAGE IN THE GROUP & AVERAGE IN THE GROUP & - \\
\hline KBE 162.28 & KBE 155.55 & KBE 50.00 & \\
\hline All sectors 68.42 & All sectors 99.89 & All sectors 81.25 & \\
\hline Baltinavas & Dagdas & Ciblas & \\
\hline KBE 0.00 & $\mathrm{KBE}+100.00$ & $\mathrm{KBE}+100.00$ & \\
\hline All sectors 77.78 & All sectors 97.56 & All sectors 100.00 & \\
\hline Rēzeknes & Kārsavas & Zilupes & \\
\hline $\mathrm{KBE}+121.43$ & $\mathrm{KBE}+333.33$ & KBE 0.00 & \\
\hline All sectors 60.82 & All sectors 95.45 & All sectors 62.50 & \\
\hline Riebinu & Aglonas & & \\
\hline $\mathrm{KBE}+600.00$ & $\mathrm{KBE}+33.33$ & & \\
\hline All sectors 106.67 & All sectors 106.67 & & \\
\hline \multicolumn{4}{|l|}{ Viliakas } \\
\hline \multicolumn{4}{|l|}{$\mathrm{KBE}+100.00$} \\
\hline \multicolumn{4}{|l|}{ All sectors 39.29} \\
\hline \multicolumn{4}{|l|}{ Vilâanu } \\
\hline \multicolumn{4}{|l|}{ KBE - 10.00} \\
\hline All sectors 57.58 & & & \\
\hline
\end{tabular}

Source: the authors' calculations according to Lursoft data, RDIM 2015, SRDA 2010, 2011, 2012

Taking into account also the development rate of the districts, it is necessary to emphasize the marked differences between the districts and the modest growth of the KBE segment in the districts with the above average or high development rates as compared to the low or medium development districts. For example, in districts with a low development rate and also low development level, the growth of the KBE segment $(+162.28 \%)$ exceeds almost three times the overall growth rate of business (+68.42). However, in this group of districts there are also marked differences between the districts according to the growth rates of the KBE segment (e.g., Riebiṇu district $+600.00 \%$, Baltinavas district $+0.00 \%$, Viḷānu district $-10.00 \%$ ). In the group of districts with a development rate above the medium or high development rate, the number of districts is considerably smaller. Among these districts, only Daugavpils and Ciblas districts demonstrate a significant increase in the KBE segment $(+94.44 \%$ and $+100.00 \%$ respectively). In other districts of this group, the growth of the KBE segment did not occur or did occur to a lesser extent than the increase in business in the economy as a whole.

The well-established tendencies suggest that rural areas in the Latgale region have the potential to develop a knowledge-based economy (see Table 3). However, these tendencies have not yet sufficiently reflected the improvement of the development of the districts.

There is practically no interconnection between the growth of the KBE segment (by number of companies) and the Smart Development Index in the Latgale region. At this stage of the analysis, this is due to the marked differences in districts according to the increase of the KBE segment. The second reason is the difference in the population density in the districts, since 11 of the 19 Latgale region districts have a low population (1112-7686 inhabitants), which also affects the economic performance results due to the limited amount of human resources. In addition, these 11 districts also have low development rate.

The results of the calculation show, that the highest average increase of the KBE segment $(+116.51 \%)$ is in the group of districts with the lowest number of inhabitants and low development rate in comparison with the more populated districts with more rapid development rate, where the average increase of the KBE segment in the group was $+75.03 \% ;+50.00 \%$; and $+107.93 \%$ respectively. It should be noted that in the group of districts with the smallest population and low development rate, there is also the highest indicator according to the increase of business in general $(+118.84 \%)$. However, it should also be noted, that the increase in the KBE segment of the group of least population and low development rate was mostly at the expense of two districts - Riebinu district $+600.00 \%$ and Kārsavas district $+333.33 \%$. In other districts of this group, the increase of the KBE segment was lower and similar to more populated districts and districts, which progress more rapidly in developing, but some districts demonstrated a zero increase or even a decrease in the KBE segment. As a positive trend, it can be mentioned that in the most populated districts with a rapid development race, the increase of the KBE segment was more rapid than the increase of business activity in the whole 
economy (for example, in Daugavpils district (+94.44\%) and Rēzekne district (+ 121.43\%)) (see Table 3). This suggests that knowledge-based sectors that are important for economic development are being emphasised.

Table 3. The increase in the number of companies in the Latgale region districts according to the number of inhabitants

\begin{tabular}{|c|c|c|c|}
\hline (I) LOW RATE & (II) RATE BELOW AVERAGE & (III) RATE ABOVE AVERAGE & (IV) HIGH RATE \\
\hline \multicolumn{4}{|c|}{ Population (thousand) } \\
\hline $1112-7686$ & $7686-14256$ & $14256-20826$ & 20826-27396 \\
\hline DISTRICTS: & DISTRICTS: & DISTRICTS: & DISTRICTS: \\
\hline AVERAGE IN THE GROUP & AVERAGE IN THE GROUP & AVERAGE IN THE GROUP & AVERAGE IN THE GROUP \\
\hline KBE 116.51 & KBE 75.03 & KBE 50.00 & KBE 107.93 \\
\hline All sectors 118.84 & All sectors 61.02 & All sectors 57.03 & All sectors 104.28 \\
\hline Aglonas & Balvu & Krāslavas & Daugavpils \\
\hline$K B E+33.33$ & $K B E+50.00$ & $K B E+50.00$ & $K B E+94.44$ \\
\hline All sectors 106.67 & All sectors 50.96 & All sectors 57.03 & All sectors 43.46 \\
\hline Baltinavas & Dagdas & & Rēzeknes \\
\hline$K B E 0.00$ & $K B E+100.00$ & & $K B E+121.43$ \\
\hline All sectors 77.78 & All sectors 97.56 & & All sectors 60.82 \\
\hline Ciblas & Ludzas & & \\
\hline$K B E+100.00$ & $K B E+55.56$ & & \\
\hline All sectors 100.00 & All sectors 47.97 & & \\
\hline Rugāju & Līvānu & & \\
\hline$K B E-50.00$ & $K B E+69.57$ & & \\
\hline All sectors 83.33 & All sectors 49.69 & & \\
\hline Vārkavas & Preiḷu & & \\
\hline$K B E+100.00$ & $K B E+100.00$ & & \\
\hline All sectors 500.00 & All sectors 58.91 & & \\
\hline \multicolumn{4}{|l|}{ Zilupes } \\
\hline \multicolumn{4}{|l|}{$K B E 0.00$} \\
\hline \multicolumn{4}{|l|}{ All sectors 62.50} \\
\hline \multicolumn{4}{|l|}{ Riebiṇu } \\
\hline \multicolumn{4}{|l|}{$K B E+600.00$} \\
\hline \multicolumn{4}{|l|}{ All sectors 106.67} \\
\hline \multicolumn{4}{|l|}{ Vilakas } \\
\hline \multicolumn{4}{|l|}{$K B E+100.00$} \\
\hline \multicolumn{4}{|l|}{ All sectors 39.29} \\
\hline \multicolumn{4}{|l|}{ Kārsavas } \\
\hline \multicolumn{4}{|l|}{$K B E+333.33$} \\
\hline \multicolumn{4}{|l|}{ All sectors 95.45} \\
\hline \multicolumn{4}{|l|}{ Ilūkstes } \\
\hline \multicolumn{4}{|l|}{$K B E+75.00$} \\
\hline \multicolumn{4}{|l|}{ All sectors 77.97} \\
\hline \multicolumn{4}{|l|}{ Viliānu } \\
\hline$K B E-10.00$ & & & \\
\hline All sectors 57.58 & & & \\
\hline
\end{tabular}

Source: the authors' calculations according to Lursoft data, RDIM 2015

The general trend of business growth shows that the people in Latgale region's rural areas relatively actively engage in business, including in the KBE segment, however, despite this, the Latgale region still has a high proportion of low-populated districts and districts with a low development race.

\section{CONCLUSIONS}

- The most significant regional development problem, which is characteristic throughout the territory of Latvia, is the significant differences in the level of socio-economic development both between regions at national level and between the districts, not only within the country but also within a specific region.

- There is a marked inequity among the Latgale region districts and the Smart Development Index in the Latgale region districts reflects the division of districts into two similar groups, where the first group has 10 districts with positive values of the index and the second group has 9 districts with negative index values. However, as a result of the qualitative research, in general as the most significant smart territory growth direction in Latgale the people cantered development scenario has been raised, due to the fact that people attraction, retention and successful usage of their potential in the districts and in general is an important factor in ensuring sustainable development.

- In general, the qualitative assessment points to the dimensions People and Economy as the basis for the smart specialization of the Latgale region. It should be noted that the dimension People clearly dominate both in quantitative and in qualitative assessment. At the same time, experts acknowledged that people's initiatives and activities play an important role in ensuring the region's smart specialization, but the institutional environment of local importance is prevalent.

\section{ACKNOWLEDGEMENT}

The publication has been created in the framework of the project „Economic transformation, smart growth, governance and legal framework for sustainable development of the state and society - a new approach to the creation of a sustainable learning community" (EKOSOC-LV) 


\section{REFERENCES}

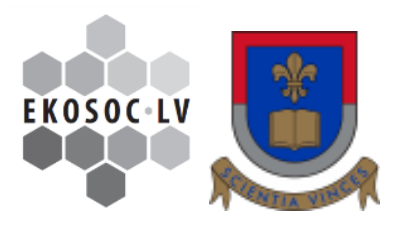

1. Carayannis, E.G., Campbell, D.F.J. 2006. Knowledge creation, diffusion, and use in innovation networks and knowledge clusters. A comparative systems approach across the United States, Europe and Asia (pp. 1-25).

2. Carayannis, E.G., Campbell, D.F.J. 2012Mode 3 knowledge production in quadruple helix innovation systems. 21st-century democracy, innovation, and entrepreneurship for development. SpringerBriefs in business, Vol. 7 Springer, New York. http://www.springer.com/business+\%26+management/book/978-1-4614-2061-3

3. Guide to Research and Innovation Strategies for Smart Specialisations (RIS 3) EC, 2012

4. ESPON, University Rovira i Virgil. 2012. 2015. ATTREG ñ The Attractiveness of European Regions and Cities for Residents and Visitors. Retrieved Available at: https://www.espon.eu/export/sites/default/Documents/Projects/AppliedResearch/ ATTREG/FR_20130123/ATTREG_FR.pdf

5. Krueger, R. 2010. Smart growth and its discontents: An examination of American and European approaches to local and regional sustainable development. Documents D'Analisi Geografica, Vol.56/3, pp.409-433.

6. Latgales plānošanas regiions 2010a, 2010b. [In Latvian]

7. Latgales plānošanas regions. 2010a. Latgales attīstības stratēǵija 2030. Retrieved 17 October 2016, from http://www.latgale.lv/lv/padome/planosana [In Latvian]

8. Latgales plānošanas regions. 2010b. Latgales plānošanas reǵiona attīstības programma 2010-2017. Esošās situācijas analīze. Retrieved 17 October 2016, Available at: http://www.latgale.lv/lv/padome/planosana [In Latvian]

9. Paliokaite, A., Martinaitis, F., Reimeris, R. 2015. Foresight methods for smart specialisation strategy development in Lithuania. Technological Forecasting and Social Change, Vol. 101, pp. 185-199. doi: https://doi.org/10.1016/j.techfore.2015.04.008

10. Regional Development Indicators Module of Spatial Development Planning Information System (RDIM). 2015. Data Tables. Available at: http://www.raim.gov.lv

11. State Regional Development Agency (SRDA). 2010. Development of Regions in Latvia 2009. Annex. 4.: Development Indexes of the Planning Regions and Administrative Territories Existing since July 1, 2009. Available: http://www.vraa.gov.lv/uploads/Development_of_Regions_2009.pdf

12. State Regional Development Agency (SRDA). 2011. Development of Regions in Latvia 2010. Annex. 2.: Planning Region, Republican City and Novads Territory Development Indexes. Retrieved 10 August 2015, from http://www.vraa.gov.lv/uploads/Development_of_Regions_in_Latvia_2010_web_ENG.pdf

13. State Regional Development Agency (SRDA). 201). Development of Regions in Latvia 2011. Annex 2: Territorial Development Indices of Planning Regions, Cities and Municipalities. Available at: http://www.vraa.gov.lv/uploads/regionu\%20parskats/Regionu\%20attistiba\%20Latvija\%202011\%20ENG_Q_ia\%20kartes\%20ho rizontali.pdf

14. Using the Quadruple Helix Approach to Accelerate the Transfer of Research and Innovation Results to Regional Growth stakeholders. European Union, 2016.

15. https://cor.europa.eu/en/documentation/studies/Documents/quadruple-helix.pdf

16. Vanthillo, T., Verhetsel, A. 2012. Paradigm change in regional policy: Towards smart specialisation? Lessons from Flanders (Belgium). Belgeo, No. 2, Inaugural Issue. https://doi.org/10.4000/belgeo.7083

17. Šipilova, V., Ostrovska, I., Jermolajeva, E., Aleksejeva, L., Oḷehnovičs, D. 2017. Evaluation of Sustainable Development in Rural Territories in Latgale Region (Latvia) by Using the Conception of Smart Specialization. Journal of Teacher Education for Sustainability, Vol. 19, Iss. 1, pp. 82-105. https://doi.org/10.1515/jtes-2017-0006

18. Šipilova, V., Aleksejeva, L., Ostrovska, I. 2015. Regional development in small municipalities: Place- and people-based approaches in context of process and result. Proceedings of The 26th International Business Information Management Association Conference (November 11-12, 2015, Madrid, Spain) "Innovation Management and Sustainable Economic Competitive Advantage, pp. 189-201. 